\title{
Reprints on Axillary Masses in Breast Cancer: A Review
}

\author{
Wilson Onuigbo* \\ Department of Pathology, Medical Foundation \& Clinic, Nigeria
}

Submission: May 23, 2018; Published: July 06, 2018

*Corresponding author: Wilson Onuigbo, Department of Pathology, Medical Foundation \& Clinic, 8 Nsukka Lane Enugu, Nigeria; Email: wilson.onuigbo@gmail.com

\section{Abstract}

An Editor stated concerning the traffic in the reprint request (RR) that I am the world's top researcher on it. Let me confirm this with an interesting phenomenon, namely, the axillary mass in cancer of the breast. This was done with a dozen reprints received during the 1980 to 1989 decade. Moreover, the author's interest in reproductive medicine was discussed by using only 3 reprints to hypothesize on brightening the outlooks of the woeful disease of gestosis.

Keywords: Reprints; Breast; Cancer; Axilla; Metastasis; Women; Gestosis; Hypothesis; Reproduction; Axillary lymph; Primary lesion; Occult; Nonpalpable; Prognosis; Tumor size; Clinical stage; Metastasis; Anatomic variant; Xeroradiography; Elecronmicroscopic; Preinvasive; Carcinoma

Abbreviations: RR: Reprint Request

\section{Introduction}

In 1986, John Swales, the Editor of English for Specific Purposes, researched on the worldwide traffic in the reprint request (RR) and wrote about me as "the only active researcher that I have traced in the RR area" [1]. Perhaps, a sequel to this honor is to use the dozen reprints which I collected during the 1980-1989 period to expatiate on the intriguing phenomenon of how the axillary lymph nodes have been featuring so much in breast cancer cases [2-13].

\section{Method}

These reprints have been analyzed from several angles. A starting point is the array of the cited Journals, namely, Cancer $[2,3,12]$, Journal of Surgical Oncology [4,11]. Annals of Surgery [5,8], American Journal of Surgical Pathology [6], Histopathology [7], Breast Cancer Research and Treatment [9]. The American Surgeon [10], Surgery [12], and Human Pathology [13]. Another point is the country of origin. Certainly, USA super abounded. Incidentally, I had previously demonstrated the premier position of USA in the reprint's traffic [14]. Next, Canada, Norway, Italy and Israel also featured.

\section{Results}

A case report came from Canada while 2 cases were presented fromUSA[10].The resttotaled2,542 cases. With regard to thesingle case report, there was eventually no evidence of a primary lesion in the breast called "occult" breast cancer, this was defined as "nonpalpable breast carcinoma presenting as an axillary mass" [10]. Following the study of 48 such patients carried out in New York for at least 5 years, it was concluded thus: "the actual pathologic stage, which takes tumor size into consideration, determines prognosis rather than the apparent clinical stage described when the patient is first examined" [13]. This was confirmed years later [6].

"Skip" metastasis was also considered [5,8]. It was defined as "involvement of lymph nodes (which) occurs in a stepwise continuous fashion from the periphery of the axilla medially." However, it was concluded that the risk is not great and "should not be a major consideration in therapeutic decisions" [8].

The sinuses of the axillary lymph nodes were also studied in Norway [7]. Apparently, they depended on Halsted's observation in 1898, and were purely mechanical. Likewise, fatty changes came into view, but it was concluded that "the presence of fat in axillary lymph nodes does not influence implantation of tumor cells from a primary carcinoma of the breast and has to be reported as an anatomic variant"[11]. Another question arose. An Italian group tackled it. They concluded thus: "When the nodes at the first level are positive, the chances that metastases are also present at the higher levels are of the order of $40.0 \%$ " 
[12]. Another Italian group took up xeroradiography [9]. They lamented thus: "Xeroradiography does not appear to have improved our ability to identify axillary lymph node metastases in patients with breast cancer". Light elecronmicroscopic examination was carried out in USA. The conclusion ran thus: "The finding of carcinoma that appears histologically to be entirely preinvasive, whether duct or lobular in type, in a breast biopsy specimen does not entirely preclude the possibility of metastases in axillary lymph nodes."

What of sampling procedures? The question boiled down to "an axillary sampling instead of a complete axillary dissection". The answer was as follows: "the possibility exists that node "sampling" understages patients who would otherwise have received adjuvant chemotherapy to improve their chances for cure." Perhaps, the answer is that of Patel's group, namely, "carcinoma found in an axillary node should be treated as a breast cancer, even in the absence of the breast tumor."

\section{Discussion}

The above data have dealt with Reprints in the field of reproductive medicine. In fact, these reprints are the old champions in the Communication Sciences. What of the reigning Internet? In this context, what of combining the old and the new? I did so with the 2004 work published on the doleful disease of gestosis. It was Chappell who lamented that gestosis contributed "to at least 40000 to 60000 of these deaths worldwide each year" [14]. Fortunately, I had received 3 reprints concerning gestosis during the $1980 / 1981$ period [15-18]. Using them, I hypothesized that, since gestosis was appreciated thrice as being linked with "new father," "new partner," and "different consort," the "women at risk ought to be so educated as to be aware of the known repercussions associated with change in paternity". As I concluded, "in all probability, the gloom of gestosis can give way smoothly to that bloom of placid parturition which must naturally follow the above enumerated enlightened sexual behavior." In particular, the Allied Health Professionals should be involved because this is not a question of prestige but of cooperation [20]. If they do so with the obstetricians, the 40000 to 60000 deaths worldwide would become history.

\section{References}

1. Swales J (1986) ESP in the big world of reprint requests. English Specific Purposes 5(1): 81-85.

2. Rosen PP (1980) Axillary lymph node metastases in patients with occult noninvasive breast carcinoma. Cancer 46(5): 1298-1306.
3. Patel J, Nemoto T, Rosner D, Dao TL, Pickren JW (1981) Axillary lymph node metastasis from an occult breast cancer. Cancer47(12): 29232927.

4. Honore LH (1980) Metastatic carcinoma in axillary lymph nodes without pathologic evidence of a primary mammary lesion: A case report. J Surg Oncol 14(4): 295-300.

5. Boova RS, Bonanni R, Rosato FE (1982) Patterns of axillary nodal involvement in breast cancer. Ann Surg 196(6): 642-644.

6. Rosen PP, Saigo PE, Braun DW, Beattie EJ, Kinne DW (1982) Occult axillary lymph node metastases from breast cancers with intramammary lymphatic tumor emboli. Am J Surg Pathol 6(7): 639641.

7. Hartveit F (1982) The sinus reaction in the axillary nodes in breast cancer related to tumour size and nodal state. Histopathology6(6): 753-764.

8. Rosen PP, Lesser ML, Kinne DW, Beattie EJ (1983) Discontinuous or "skip" metastases in breast carcinoma. Ann Surg 197(3): 276-283.

9. Coopmans de Yoldi GF, Andreoli C, Costa A, Nessi R, Gilardoni L, et al. (1983) Lack of efficacy of xeroradiography to preoperatively detect axillary lymph node metastases in breast cancer. Breast Cancer Res Treat 3(4): 373-376.

10. High RM, Watne AL (1984) The axillary mass in occult breast carcinoma. Am Surg 50(11): 630-636.

11. Werbin N (1984) Fatty changes and metastases in axillary lymph nodes. J Surg Oncol 25(3): 145-147.

12. Pigott J, Nichols R, Maddox WA, Balch C (1984) Metastases to the upper levels of the axillary nodes in carcinoma of the breast and its implications for nodal sampling procedures. Surgery 158: 255-259.

13. Rosen PP, Kimmel M (1990) Occult breast carcinoma presenting with axillary lymph node metastases: A follow-up study of 48 patients. Hum Pathol 21(5): 518-523.

14. Onuigbo WIB (1985) Reprint requests-a tool for documentation. Intl Forum Inform Document 10:7-9.

15. Chappell L(2004) Recent advances in pre-eclampsia and eclampsia. Trop Doctor 34:1.

16. Ikedife D (1980) Eclampsia in multipara. Br Med J 280(6219): 985-986.

17. Marx GP, Habib NS, Schulman H (1981) Is pre-eclampsia a disease of the sexually active gravid? Med Hypotheses 7:1397-1399.

18. Feeney JG, Scott JS (1980) Pre-eclampsia and changed paternity. Eur J OBstet Gynecol Reprod Biol 11(1): 35-38.

19. Onuigbo WIB (2016) Can allied health care professionals assist obstetricians in preventing gestosis and promoting safe childbirth? Res Chron Health Sci 2(4): 280-282.

20. Parker HJ, Chan P (1987) Prestige ratings of allied health professions. Texas Med 83: 49-51. 
(C) This work is licensed under Creative CC) (1) Commons Attribution 4.0 License BY DOI: 10.19080/GJORM.2018.05.555658
Your next submission with Juniper Publishers will reach you the below assets

- Quality Editorial service

- Swift Peer Review

- Reprints availability

- E-prints Service

- Manuscript Podcast for convenient understanding

- Global attainment for your research

- Manuscript accessibility in different formats ( Pdf, E-pub, Full Text, Audio)

- Unceasing customer service

Track the below URL for one-step submission https://juniperpublishers.com/online-submission.php 